\title{
ANNUAL GENERAL MEETING
}

The 75th Annual General Meeting will be held in the Meeting Rooms of the Zoological Society of London, Regent's Park, London NW1 on Wednesday, July 41979 at $6 \mathrm{pm}$. The speaker will be Professor Kai Curry-Lindahl of the Royal Ministry for Foreign Affairs in Stockholm and an FPS Vice-President. Saga of the Sea Otter, a film on the marine otter of South California, will be shown courtesy of Survival Anglia Ltd. A wine and cheese supper will be served.

\section{Agenda}

1. Minutes of the 1978 Annual General Meeting

2. Presentation and discussion of Annual Report

3. Presentation and discussion of the Accounts and Auditors' Report

4. Election of Officers

5. Election of Vice-President

6. Election of Council Members

7. Proposed amendment to Rule 2-Subscriptions: Ordinary members $£ 10.00$ annually. Other subscriptions pro rata

8. Vote of thanks to Zoological Society of London

Council recommends that the following members should be re-elected as Officers of the Society for 1979-80:

President Professor Lord Zuckerman OM KCB DSc FRS

Chairman of Council Sir Peter Scott CBE DSC

Vice-Chairman of Council Lord Craigton PC CBE

Honorary Treasurer Ian D. Malcolmson TD

Honorary Secretary Richard Fitter

Honorary Editor Maisie Fitter

The following member is proposed for election as Vice-President:

David Attenborough

Three members of Council retire at the Annual General Meeting and are not eligible for re-appointment for one year:

Dr G. C. L. Bertram

Dr David Harrison

Dr E. Barton Worthington

Council has appointed the following to fill the vacancies and their names are submitted for confirmation:
R. E. Boote
J. Hancock
Dr R. E. Stebbings 


\section{ANNUAL REPORT for 1978}

\section{Vice-Presidents and Council}

It is with great regret that we record the death of the 4th Earl of Cranbrook on November 22 1978. An active conservationist and parliamentarian, who introduced both the Conservation of Wild Creatures and Wild Plants Act, and the Conservation of Seals Act, he was a member of the FPS Council from 1966 until 1971 and a Vice-President from 1976 until the time of his death.

Three new members were elected to Council: Mr J. M. Knowles, Director of Marwell Zoo, one of the leading zoos in the field of breeding endangered species, including Grevy's zebra and scimitar-horned oryx; Dr R. D. Martin, primatologist and lemur specialist who edited the proceedings of the First World Conference on Breeding Endangered Species in Captivity on behalf of FPS; and Lord Medway (now 5th Earl of Cranbrook) who returns for a second term.

\section{5th Anniversary of FPS}

1978 was the 75 th Anniversary of the Society and a number of events marked the occasion. The most important was the publication of The Penitent Butchers. Written by the Honorary Secretary and illustrated by the Chairman, it is a history of the international conservation movement and the Society's part in it. The publication of the book was marked by a reception, at the kind invitation of Martini Rossi, held at the Martini Terrace, New Zealand House, on December 7th, which was attended by the President, Lord Zuckerman, the author and artist, members of Council and friends of the Society.

A Members' Meeting on December 19, closer to the actual date of the foundation of the FPS showed the Society's historic film, Operation Oryx. The Zoological Society of London kindly allowed FPS to mount an exhibition in the Elephant House, which created considerable interest among visitors for most of the year.

A lapel badge with the Society's symbol was produced and is still available (now 30p).

\section{Oryx}

Two issues of Oryx were published, a 96-page issue in June, and a double issue of 160 pages to celebrate the Society's 75 th anniversary in November. The November issue contained an important paper on the status and distribution of the Asian elephant by Robert Olivier, Co-Chairman of the IUCN Asian Elephant Group.

\section{International Meetings}

During 1978 the Society was represented by one or other or all of the Honorary Secretary, Honorary Editor and Executive Secretary, at the following meetings: IUCN Survival Service Commission, Faro, Portugal in February; International Whaling Commission, London, June and Tokyo, December; and IUCN General Assembly and Survival Service Commission in Ashkhabad, Turkmen SSR in September/October.

\section{Membership}

At the end of 1978 there were 423 Life Members, and 2664 Benefactor and Ordinary Members. A new student member category of $£ 3.00$ per annum was introduced. The publicity for the plight of the mountain gorilla: a WWF dispatch of the Penitent Butchers leaflet and an advertisement in the New 
Scientist brought a total of 208 new members in at the end of the year. After deletions for non-payment of subscriptions membership at the end of the year was 3295 .

\section{Oryx $100 \%$ Fund}

Gifts to the Oryx $100 \%$ Fund in 1978 totalled $£ 7241.84$ of which $£ 5000.00$ was earmarked for special projects (Greenpeace $£ 4000.00$ and EAWLS $£ 1000.00$ ). The Mountain Gorilla Fund raised the sum of $£ 22,373.21$ (as at 31.12.78). Donations were received from Major Ian Grimwood $£ 1000.00, \mathrm{Dr} M$. C. Dawbarn $\AA^{400.00}, \mathrm{~S} . \mathrm{F} . \mathrm{M}$. Rostron $\AA^{60.00}$, K. Richards $\AA^{50.00}$, Lt Col G. A. E. Gibbs $£ 50.00$, E. G. H. Lewis $£ 50$, Brigadier E. F. Maude $£ 50.00, P$. Sugden $£ 50.00, M$. Fitter $£^{30.00}$ and Miss E. Hickok $£ 20.00$. (The sum of $£ 1500.00$ was repaid to an anonymous donor on account of a cancelled project). The Fund aided projects in Argentina, Brazil, Chile, Galapagos, Guyana, Dominica, Costa Rica, Seychelles, Cameroon, Ghana, Kenya, Tanzania, Rwanda, Liberia, Madagascar, Thailand, Nepal, India, Sri Lanka and Greenland.

\section{Legacies and Gifts}

Six legacies were received in 1978: Miss H. D. Tilly $£ 4839.34, \mathrm{~L}$. Sherrif $£ 2583.12$, Miss E. Jagger $£ 1985.47$, Mrs L. K. Nye $£ 1000.00$, Miss C. K. McMullen $£ 500.00$ and Mrs G. M. Soward $£ 25.06$.

Gifts received amounted to $£ 7827.26$, including Nationwide $£ 2734.30$, Anonymous $£ 2000.00$, New Moorgate Trust $£_{1000.00}$, St Katharine's Fund $£ 800.00$, Ofenheim Charitable Trust $£ 200.00, \mathrm{~J}$. D. Constable $£ 156.00$, Ernest Kleinwort Charitable Trust $f 100.00, M r s$ M. J. Hayne $£ 100.00, F$. Hammer £84.54, A. I. G. Ramsay $£ 76.00$, Mrs A. Ahlers $£ 50.00, \operatorname{Dr}$ A. A. Spriggs $£ 50.00$, A. E. Cole $£ 50.00$, Mrs R. H. Taylor $£ 50.00$, Mrs V. H. Williams $£ 25.00$, Miss M. R. Silverman $£ 20.00$ and A. L. Hardman $£ 20.00$

\section{Otter Haven Project}

The Otter Haven Project, financed by the Vincent Wildlife Trust continued, and during the course of the year expanded to take on three more co-ordinators, so that the area covered could be expanded. A booklet, called The Otter, was produced in April 1978, by Vincent Weir for the Otter Haven Project.

TRAFFIC (Trade Records Analysis of Flora and Fauna in Commerce) The FPS continues to administer and support the IUCN/SSC TRAFFIC group which continues to expand its operations. A large volume of reports and publications have emanated from the TRAFFIC office, on topics ranging from the East African mollusc trade to that of harp seal pelts. A complete list of publications and reports are available from the TRAFFIC office. A Bulletin (10 issues a year) is now produced, which contains reports and summaries of the international trade in wildlife. Working in close co-operation with the RSPCA, draft guidelines for the transportation of live animals were produced and submitted to the Secretariat of CITES (1973 Convention on International Trade in Endangered Species of Fauna and Flora). TRAFFIC also provided facilities for a detailed investigation into the trade in harp and hooded seals, commissioned by the FPS and funded by the International Fund for Animal Welfare. 
Members' Meetings

The Annual General Meeting was held on July 5 th. Charles de Haes, DirectorGeneral of World Wildlife Fund International was the guest speaker. After a buffet supper The Business of Extinction, a 50-minute film on international trade in wildlife, was shown. This was also a Zoo open night.

On February 10 and 11, a two-day symposium organised jointly by FPS and the Mammal Society, entitled Mammal Conservation at Home and Abroad was held. Lord Craigton opened the proceedings, and on the afternoon of the 11 th a showing of the Chinese film on the giant panda, courtesy of the Chinese Embassy, closed it.

In 1978 five evening Members' Meetings were held. On March 9 a joint meeting was held with the World Pheasant Association and the Pheasant Trust. Philip Wayre was in the chair and speakers included K. C. R. Howman and Dr T. W. I. Lovel, and a film entitled Vanishing Pheasants was shown. On April 25 Dr G. C. L. Bertram, Chairman of the IUCN/SSC Sirenia Specialist Group, gave an illustrated talk on dugongs and manatees. Following the buffet supper the film Galapagos by Heinz Sielmann was shown. On October 26 a Gorilla meeting was held, to raise funds for the Mountain Gorilla Project. Dr A. H. Harcourt, co-ordinator of the Mountain Gorilla Project, gave an illustrated talk and following the supper, part of a film entitled In Search of the Great Apes was shown, courtesy of National Geographic, USA. On November 21, Dr Brian Bertram showed his 50-minute silent film on leopards, providing his own commentary, and this was followed by a showing of Tiger, Tiger, a Survival Anglia film, by courtesy of Lord Buxton and Anglia Television. On December 19 a meeting was held to discuss the problems of the world's arid zones. Speakers included John Knowles, Director of Marwell Zoo, who spoke on the captive breeding of scimitar-horned oryx, and Professor Peter Jewell. The film, Operation Oryx, made by Dr Michael Woodford in 1963, was shown.

\section{Office Work}

Although the volume of work and the number of projects handled by FPS has increased dramatically in the last few years, the number of staff actually employed at FPS has stayed steady. Margaret Crooks joined the staff at the beginning of 1978, and is in charge of the film library, and Kay Williams (formerly of IUCN) is now working part-time on the Society's accounts.

The FPS administers or provides facilities for the five Otter Haven Project staff, Jane Thornback (Red Data Book, Mammals) and the staff of four at TRAFFIC.

\section{Film Library}

In 1978 the film library received 120 film bookings, showing to a total audience of over 10,000. The library was expanded by the addition of The Business of Extinction, an American TV film about the trade in endangered species, which includes references to the work of CITES and IUCN's TRAFFIC group, whose Chairman is the Executive Secretary of FPS.

Christmas Cards

For the 75th Anniversary year of the society, Sir Peter Scott painted a group of Arabian oryx and kindly gave it for use as the 1978 Christmas card. Some 25,000 were produced and about half were sold. The Society also sold several other cards and a total over 25,000 were sold. Sales totalled $£ 1912.06$. The society's insignia goods continue to sell well. 


\section{Auditors' Report}

To: The Council and Members of the Fauna Preservation Society

\section{Accounts for the year ended 31st December 1978}

We have completed the audit of the books and accounts of the Society for the year ended 3lst December, 1978 and report thereon as follows:

\section{Life Membership Fund}

The balance standing to the credit of the Fund is now $£ 14,873$. This is after crediting $£ 1,219$ in respect of Life Membership Subscriptions received during the year and transferring $£ 85$ to the General Reserve Account which represents the value of subscriptions of those life members whose membership ceased during the year.

\section{Film Purchases - Reserve Fund}

To the opening balance of $£ 1,560.75$ has been added $£ 219.34$ transferred from Income and Expenditure Account. Purchases during the year amounted to $£ 268.44$ leaving a balance to be carried forward of $£ 1,511.65$.

\section{General Reserve Account}

The balance at 1st January 1978 was

to which has been added:

Legacies

Fees of deceased life members

$£ 73,576.17$

$84,594.16$

from which has been deducted the excess of Expenditure over income for the year

Grant to Oryx $100 \%$ Fund

$8,021.90$

Loss on Investment Sales

$3,020.00$

$1,734.02$

$12,775.92$

giving a balance at year end of

$\{71,818.24$

\section{Investments}

The total investments and deposits of the Society at 31st December 1978 at cost amounted to $£ 101,097$ including $£ 16,874$ of the Oryx $100 \%$ Fund and the market value at that date was $£ 106,533$, showing a net appreciation of $£ 5,436$.

\section{Surplus}

The surplus of assets over liabilities at the end of the year amounted to $£ 88,489.35$ compared with $£ 88,906.01$ at the end of the previous year. 


\section{Oryx $100 \%$ Fund}

The balance at 1st January, 1978 was

to which has been added:

Donations
Transfer from General Purposes Account

Grants made during the year amounted to

Sundry expenses incurred

Leaving Balance at Bank at 31st December, 1978
$8,581.73$

$$
28,115.05
$$$$
3,020.00
$$

$31,135.05$

$39,716.78$

$17,987.42$

22.40

\section{Otter Account}

Grants received during the period of operation were $£ 12,700.00$, and expenditure incurred at $£ 12,546.48$ resulted in a balance of $£ 382.56$ to be carried forward.

\section{TRAFFIC Account}

To the opening balance of $£ 528.61$ has been added Grants of $£ 18,000.00$. Expenditure amounted to $£ 16,470.58$ leaving a balance of $£ 2,058.03$ to be carried forward.

\section{Oryx $100 \%$ Fund}

Year ending 31st December 1978

Balance at 1st January

\section{INCOME}

Income for year-

Donations:

Earmarked-Mountain Gorilla Project

Greenpeace

$22,373.21$

EAWLS

$4,000.00$

Others

Transfer from General Purposes Fund 
Books for Serengeti Research Institute $\quad 55.12$

WNPS of Ceylon: Tourist Leaflets 250.00

Juan Fernandez Fur Seal (Daniel Torres-Navarro) $\quad 502.56$

Study of Huemul in Chile (G. Stutzin) 300.00

Study of Pileated Gibbon (S. Srikosarmatara) 250.00

Nepal Expedition (University of East Anglia) 500.00

Management Programme for Turtles (Dr. E. Moll) 250.00

Himalayan Tahr survey (M. Green) 500.00

Sullom Voe Oil Terminal Study (Dr. J. A. Fowler) 20.00

Fruit Bat survey (Oxford Expedition to Mount Nimba) $\quad 100.00$

University of Aberdeen Expedition to Sri Lanka 250.00

Indri \& Lemur study in Madagascar (J. I. Pollock) 250.00

Ecological Expedition to Tanzania (S. Stuart) 250.00

Ecology study of the Dhole (A. J. T. Johnsingh) 250.00

Sea-bird studies, Galapagos (Craig MacFarland) 250.00

Ecology of Phelsuma (Miss C. Crawford and Dr Thorpe) 250.00

Assistance at Madras Crocodile Bank (J. H. Craig) $\quad 100.00$

Expedition to Mole National Park (Aberdeen University) $\quad 50.00$

Expedition to Guyana (Durham University) 250.00

Brown howler monkey study (Espedito C. da Silva, Jr.) $\quad 400.00$

Himachal Wildlife Project (Garson, Hunter and Gaston) 220.00

Cebidae in Sao Paulo, Brazil (C. Torres de Assumpcao) $\quad 100.00$

Expedition to Dominica (Aberdeen University) $\quad 50.00$

Joint Chagos Research Expedition (P. Davis) 200.00

Biotope Preservation on Tagus River (J. Garzon) 250.00

Endemic bird study, Seychelles (P. W. Greig-Smith) $\quad 100.00$

Ecology of Liolana iolas (L. McLeod) $\quad 59.00$

Endangered species study in Costa Rica (James T. Lewis) $\quad 300.00$

Badges for Rwanda National Park $\quad 318.60$

Giraffe study in Cameroon (Jean Ngog) 100.00

Assessment of Gran Chaco Fauna (Dr. C. M. Perrins) $\quad 500.00$

Financing of Crocodile Group Newsletter (R. Whitaker) $\quad 60.00$

Greenland white-fronted goose study (W. Higgs) 200.00

Organisation of Conservation Symposium of International

Primatological Congress in India (Z. Futehally) 100.00

Dark-rumped Petrel study (Darwin Research Station) 250.00

Charles Darwin Foundation

Greenpeace

E.A.W.L.S.

Mountain Gorilla Project

Bank Charges

$7,852.42$

$4,000.00$

$1,000.00$

$5,135.00$

22.40

Balance at Bank 31st December 


\section{LIABILITIES}

太.

5,279 Sundry Creditors and Provisions

$\underset{9,315.83}{\mathcal{E}} \mathrm{p}$

Receipts in Advance

732 Subscriptions

980.09

$10,295.92$

6,011

Balance, being excess of assets over liabilities :-

Life Membership Fund

Balance at 1st January, 1978

Add: Fees received during year

$13,739.00$

$1,219.00$

$14,958.00$

Deduct: Transfer to General Reserve Account:-

Fees of deceased Life Members

85.00

13,739

Film Purchases-Reserve Fund

Balance at 1st January, 1978

$1,560.75$

Add: Transfer from Income and Expenditure

Account

219.34

$14,873.00$

Deduct: Purchases during year

$1,780.09$

268.44

1,561

Red Data Book Account

30.09

Deduct: Transfer to Income and Expenditure Account

30.09

30

73,576

286.46

$71,818.24$

$£ 98,785.27$

$£ 94,917$

Seal Investigation-Transfer from Income and Expenditure Account

General Reserve Fund

$1,511.65$

We have examined the above Balance sheet and accompanying Income and Expenditure Account, the Receipts and Payments Accounts relating to the Oryx 100\% Fund, the TRAFFIC and Otter Accounts, with the books and accounts of the Society and with the information and explanations supplied and certify them to be in accordance there with. We have verified the bank balance and the investments of the various funds.

Knightway House,

20, Soho Square,

LONDON, WIV 6QJ.

13th March, 1979.

NORTON KEEN \& CO.,

Chartered Accountants. 
1977

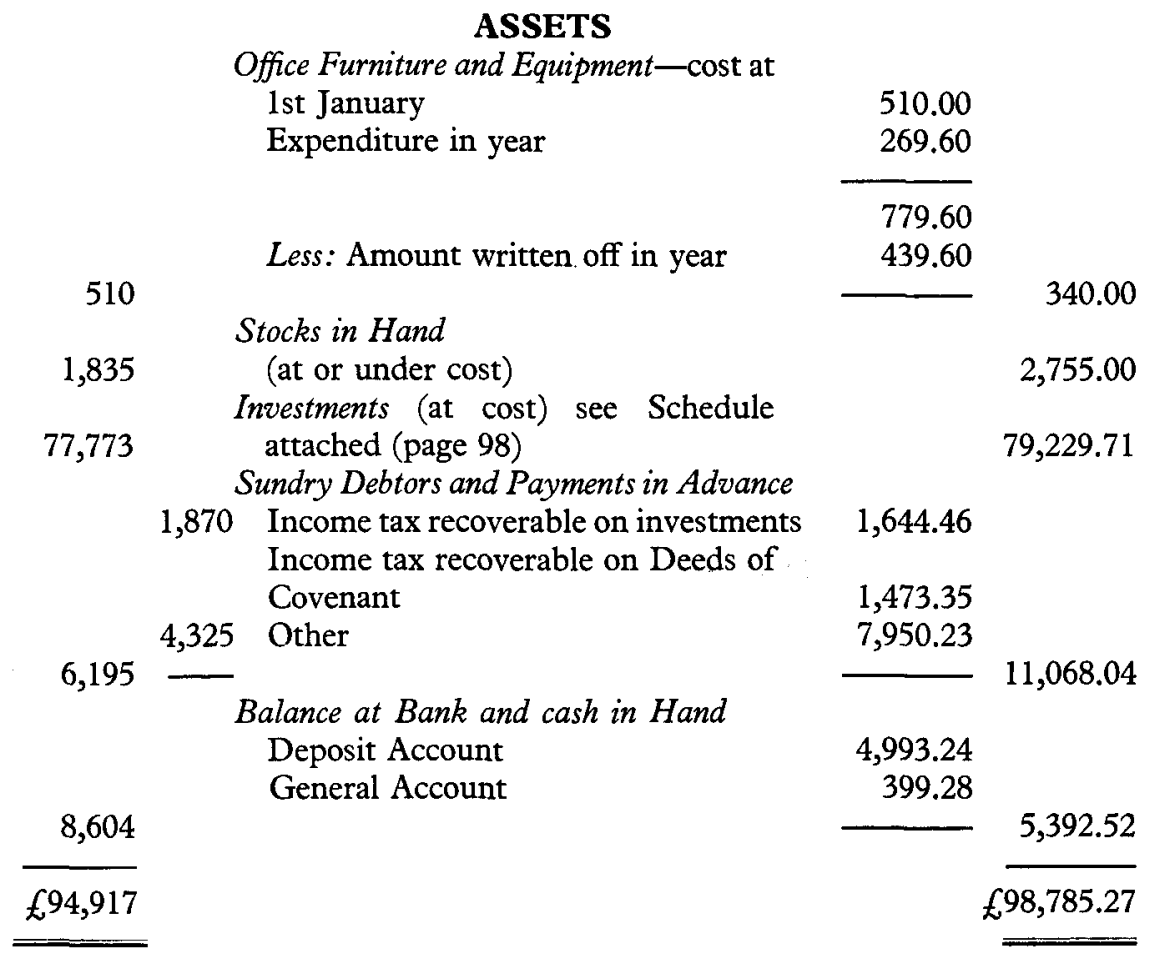

\section{Otter Account}

Year to 31st December, 1978

Balance at 1st January

Grants received during year 229.34

$12,700.00$

Expenditure
Salaries
Miscellaneous

$12,929.34$

$86,88.62$

$3,858.16$

Balance at 31st December

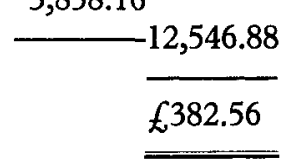


$£$

\section{EXPENDITURE}

7,533 Salaries-Office Manager and Secretarial staff

$£ \mathrm{p}$

$£ \mathrm{p}$

$12,935.37$

4,200 Consultancy fees

Hon. Editor's expenses including Survival

$4,944.24$

188 Services Commission of IUCN

638.98

Hon. Secretary's overseas expenses including

1,022 S.S.C. of IUCN

684 Hon. Secretary's local travelling

162 Assistant Secretary's travelling expenses

7,912 Production of Journal

1,444 Postage for Journal $\quad 1,643.64$

$1,708.36$

648.50

790.95

$9,135.29$

Office-Service charge

Regent's Park-net

- Less: Donation from Zoological Society 250.00

978 Office and miscellaneous expenses

894.80

767 Stationery

$2,993.97$

419.71

1,332 Telephone

$1,775.93$

234 Advertising

$1,974.53$

1,162 Postage

720 Accountancy and audit

$2,109.60$

532.40

40.00

40 Income tax-accountancy charges

500.00

2,627 Transfer to ORYX $100 \%$ Fund

- Miscellaneous grants to projects

204 Furniture and equipment-amount written off

24 Sundry sales-deficit

223 Game Fair 
1977

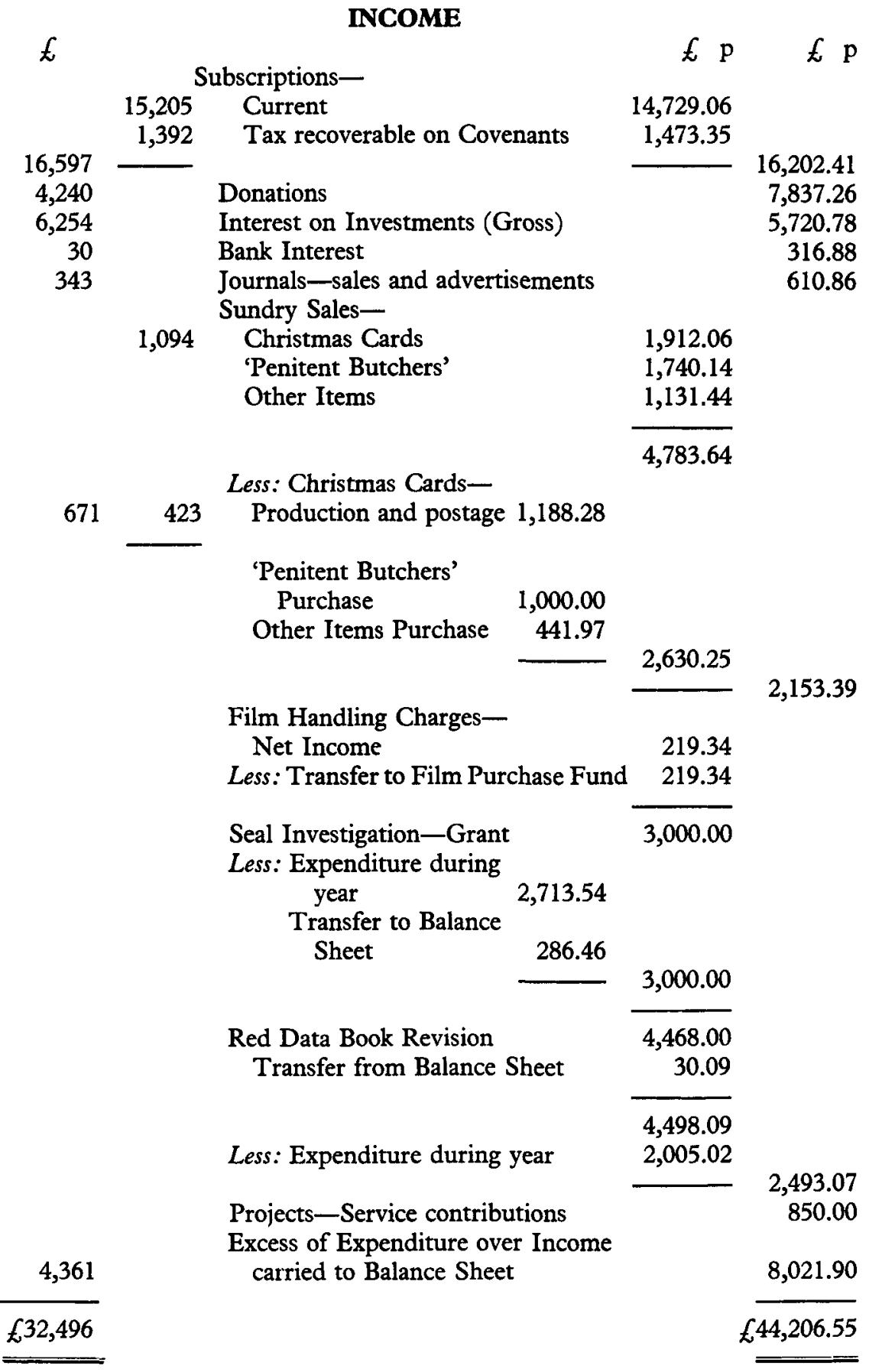


3,000.00 Greater London $9 \frac{1}{4} \%$ Stock $1980 \quad 2,992.91$

2,500.00 Gestetner Holdings 10\% Culs. 1990/95 3,157.30

3,300.00 Imperial Group Ltd. 8\% Culs. 1985/90 2,452.17

2,900.00 Midland Bank Ltd. $7 \frac{1}{2} \%$ Culs. 1983/93 2,420.44

2,000.00 Slough Estates Ltd. 10\% Culs. 1987/90 3,012.80

850.00 Babcock \& Wilcox Ltd. Ordinary Shares 25p 2,450.81

$7,650.00 \quad 9 \frac{1}{4} \%$ Treasury Stock $1983 \quad 6,973.98$

100.00 Sedgwick Forbes Holdings Ltd. Ordinary 10p Shares $\quad 1,989.20$

$17,600.00 \quad 9 \frac{11 \%}{1} \%$ Exchequer Stock $1982 \quad 17,266.25$

925.00 Imperial Group Ltd. 25p Ordinary Shares $\quad 3,015.72$

125.00 De la Rue Ltd. 25p Ordinary Shares 2,178.98

800.00 Imperial Chemical Industries Ltd. Ordinary Stock $\quad 2,903.00$

3,000.00 Steetly Co. Ltd. 7\% Culs. 1984/88 2,747.85

1,838.75 Trustees Corporation Ltd. 25p Ordinary Shares 7,575.65

44.00 St. Pancras Housing Society Ltd. $2 \frac{1}{2} \%$ Conversion Stock

222.00 Shell Transport and Trading Co. Ltd. 25p Ordinary Shares

1,375.00 Scottish Eastern Investment Trust Ltd.

25p Ordinary Shares
$210.50 \quad$ Royal Insurance Co. Ltd. 25p Ordinary Stock Units

$5,995.00$

1,110.00 North American Trust 25p Ordinary Shares 3,552.00

150.00 Hambro Life Assurance Co. 25p Ordinary Shares

121.00 Midland Bank $£ 1$ Ordinary Stock

\section{TRAFFIC Account}

Expenditure

Consultants' Fees and Salaries

Special survey-Cacti

Travelling

Rent

Office expenses

$9,664.73$

452.87

901.56

$2,031.48$

$3,419.94$

Balance at 31st December

$£ 2,058.00$ 


\section{FPS Wildlife Film Library}

Unless otherwise stated all films are $16 \mathrm{~mm}$ colour with soundtrack. The charges quoted are for one screening only; additional screenings are $£ 2$, or $£ 1$ for older films. All films must be shown by an experienced projectionist. To book a film please write to the Films Officer, FPS, c/o Zoological Society of London, Regent's Park, London NWl 4RY (Tel: 01-586 0872).

Business of Extinction. A hard-hitting film dealing with trade in wildlife with particular reference to the Washington Convention. 50 mins. $£ 7.50$

The Right Whale: An Endangered Species. Roger Payne's study of the right whales off Patagonia: National Geographic film. 22 mins. $£^{7.50}$.

At the Crossroads. American wildlife's struggle for survival. Shows endangered species never filmed before. Winner of six awards. 26 mins. $£ 7.50$.

The Last Stronghold. Flying snakes, flying squirrels, and other wildlife in the Malaysian rain forests. Made by WWF Malaysia. 30 mins. $£ 5$.

In Search of the Bowhead Whale. Aerial and underwater photography of bowhead and beluga whales off Alaska. 49 mins. $£ 5$.

Bighorn. Life history of Rocky Mountain bighorn sheep. 26 mins. $f^{5}$.

Ivory Poachers. East African Wildlife Society documentary of the fight against Tsavo elephant poachers. 30 mins. $£ 5$.

On the Third Day. Rare and beautiful plants, insects and vertebrates of the Cape of Good Hope. South African Wildlife Society. 26 mins. $£ 5$.

To Catch a Rhino. Translocation of white rhinos from the Umfolozi Reserve. South African Tourist Corporation, 1962. 20 mins. $f^{3}$.

Everglades Region. How wildlife adjusts to seasonal fire and floods. 24 mins. $£^{3}$.

Lake Wilderness. Wildlife of Saint Lucia Lakes. SATOUR. 20 mins. £3.

Blesbok. Life history of this South African antelope. 15 mins. $£ 2$.

Whales, Dolphins and Men. Lives, songs and commercial exploitation of cetaceans. BBC Horizon film. 50 mins. $£ 5$.

\section{Older films}

$£ 2$ each or $£ 1$ if hired with a film from the main list.

Peace Game. South Africa's wildlife. SATOUR. 25 mins.

Saiga Saga. Conservation of the saiga antelope. Russian commentary with English subtitles: Soviet Peace Committee. 16 mins.

Koala. Complete life history. H.J. Pollock. 24 mins.

African Lion. Taken by A.I.M. Hepburn in the Kruger National Park. Magnetic sound track. 12 mins.

Mallee Fowl. Nesting habits of a 'mound builder'. CSIRO Film Unit. 11 mins.

Marloo, the Red Kangaroo. By H.J. Pollock. 25 mins.

Le Aye Aye de Madagascar. Black and white. French commentary. By J.-J. Petter and the Service du Film de Recherche Scientifique. 22 mins.

Penguins of Macquarie Island. King, gentoo, rockhopper and royal penguins. 13 mins. 


\title{
THE FAR EAST
}

Specialists for flights to the Far East:

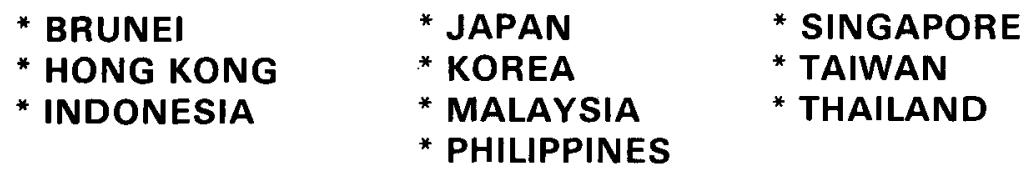

\section{MALAYSIAN \& FAR EASTERN TRAVEL LIMITED}

\author{
(MAFETA)
}

(Established 1965)

\section{Brook Street, Mayfair, London W1Y 1 AJ Telephone: 01-499 8132 Telex: 885815 Mafeta}

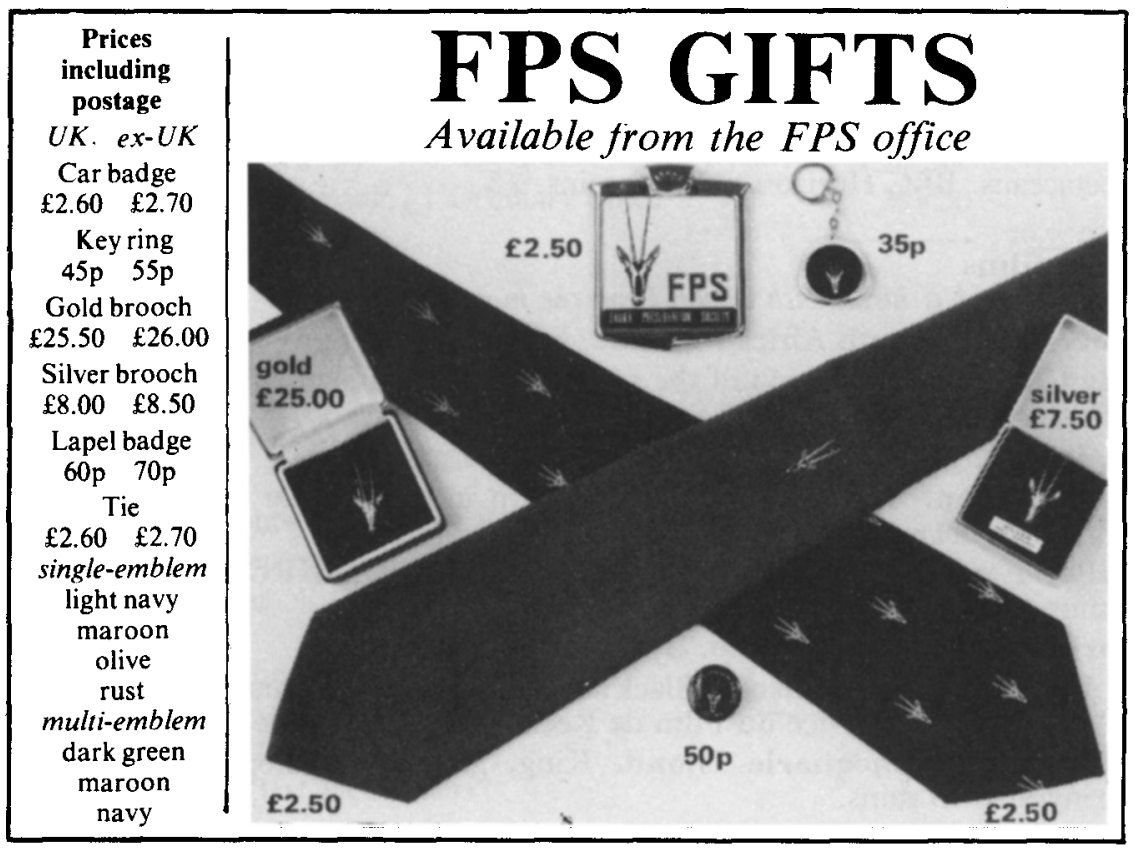




\section{ORNITHOLIDAYS}

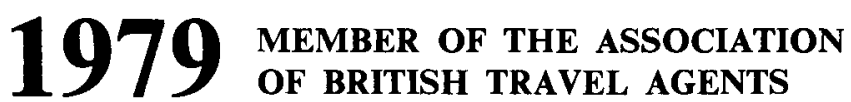

HOLIDAYS ORGANISED BY

BIRDWATCHERS FOR BIRDWATCHERS

Ceylon

India

Florida

California

The Seychelles

Kenya

Israel

Morocco

Tunisia

Turkey

Arctic Norway

S. W. Spain
Majorca

Greece

The Camargue

Yugoslavia

Lake Neusiedl

Austrian Alps

Hungary

Romania

Central Wales

Isles of Scilly

Isle of Mull

Isle of Islay

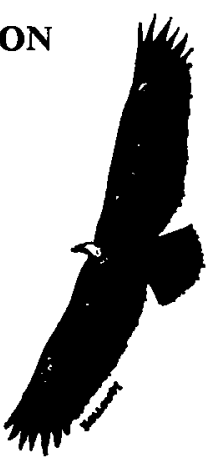

The Solway

The Cairngorms

Hebridean Cruise

Dorset

New Forest

West Sussex

Suffolk

The Farnes \& Bass

\section{LAWRENCE G. HOLLOWAY ORNITHOLIDAYS (Regd.) \\ (WESSEX TRAVEL CENTRE)}

1/3 VICTORIA DRIVE, BOGNOR REGIS, SUSSEX, ENGLAND PO21 2PW

Telephone 0243321230 


\section{Application for Membership}

\section{The Fauna Preservation Society}

c/o The Zoological Society of London, Regent's Park, London NW1 4RY

Please enrol me as a member of the Society

Name (BLOCK LETTERS) Please state Mr/Mrs/Miss or title

\section{Address}

I enclose $\boldsymbol{f}$ : :

being my subscription as a Life/Benefactor/Ordinary Member.

The minimum subscription for Ordinary Members is $£ 5$, US \$12.50, for Benefactors $£ 10$, US $\$ 25$, students $f 3$, US $\$ 7$. A Banker's Order saves time, expense and reminders. The value of any subscription is greatly increased if it is paid under a seven-year Deed of Covenant (UK standard-rate income taxpayers only) and this entails no extra cost whatever: write for Covenant forms to the Secretary.

Life membership fees:

Age: Under 41 , £200, US $\$ 485$; age $41-60, £ 150$, US $\$ 385$; age 61 and over, $£ 75$, US $\$ 185$.

\section{Banker's Order}

Bank

Address of Bank

Please pay for the Credit of The Fauna Preservation Society, Barclays Bank Ltd. Camden Town, London NW1, my subscription of $\{\ldots . . . . . . . .$. due on 1 st January 19 , and a similar amount on 1 st January each year until further notice. 


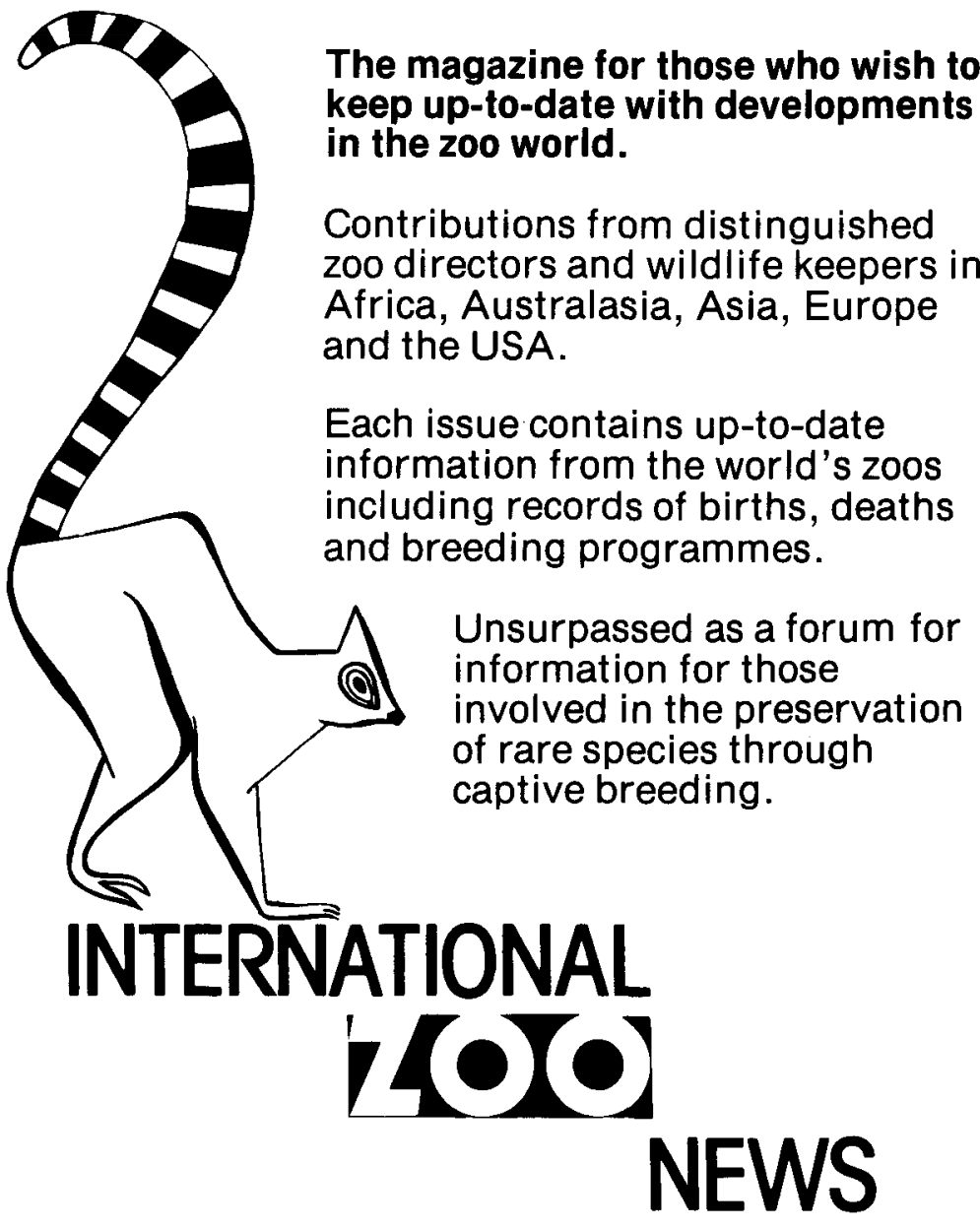

International Zoo News, Subscription Department, 73 Molesworth Street, Wadebridge, Cornwall, PL27 7DS, England.

Please send me International Zoo News 8 times a year starting with the next issue. I enclose $£ 10.00$. US $\$ 26.00$. DM. 62.50 (Post free. Airmail rate extra on application. Please make cheques payable to Zoo Centrum.)

Name:

Address:

Please send me a free copy 